УДК556.388:546.95:63

(C) 2014

Коваль В. В., директор,

Кучерявий С. О., начальник відділу геоінформаційних систем, землевпорядних робіт та охорони родючості трунтів,

Наталочка В. О., завідувач лабораторії екологічної безпеки земель, довкілля та якості продукції,

Нечитайло В. М., завідувач лабораторії забезпечення агрохімічних досліджень

Полтавська філія державної установи «Інститут охорони грунтів України»

Фесенко О. Г., аспірант

(науковий керівник - доктор сільськогосподарських наук, професор П. В. Писаренко)

Полтавська державна аграрна академія

\title{
ДИНАМІКА ЗАБРУДНЕННЯ ВОД СІЛЬСЬКОГОСПОДАРСЬКОГО ПРИЗНАЧЕННЯ ВАЖКИМИ МЕТАЛАМИ
}

Рецензент - доктор сільськогосподарських наук, професор Г. П. Жемела

Наведено результати досліджень вмісту солей важких металів у природних водоймах Полтавської області. Підкреслюється, щзо одним із забруднювачів вододжерел є хімізачія сільського господарства. Дослідження проводились у 2008-2012 роках на базі Полтавського обласного державного проектнотехнологічного центру охорони родючості трунтів $i$ якості продукиії. Результати їх показали, щчо перевищень ГДК не спостерігається, отже, є передумови для ведення в регіоні екологічного землеробства. Однак необхідною передумовою изього $\epsilon$ наявність об'єктивної інформації щодо агроекологічного стану трунтових $i$ водних ресурсів, а також впровадження екологічно безпечних технологій вирощування сільськогосподарських культур.

Ключові слова: ГДК (гранично допустима концентрація),вода, важкі метали, свинець, кадмій, цинк, мідь, ртуть.

Постановка проблеми. Вода - важлива складова нашого існування, найбільш необхідний компонент для всіх форм життя.

Не випадково вчені у пошуках життя на інших планетах сонячної системи стільки зусиль спрямовують на виявлення слідів води.

Незважаючи на свій гранично простий хімічний склад, вода - одна 3 найбільш загадкових та аномальних речовин на Землі [8].

Одним із важливих чинників нормальної життєдіяльності людини є її забезпеченість чистою та фізіологічно повноцінною питною водою.

За даними ВОО3, щороку близько $25 \%$ населення світу піддається ризику захворювань у результаті споживання неякісної води. Тривале використання води, яка має відхилення від нормативних вимог, веде до стійкого зростання захворюваності населення [9].

Без перебільшення можна стверджувати, що практично всі елементи і речовини, які використовує чи виготовляє людина, так чи інакше опиняються у гідросфері, серед яких переважають хімічні (кислоти, мінеральні солі різного складу, луги, метали і т. п).

Не меншої шкоди завдає водоймам і сільське господарство. Природно, що для одержання вищих урожаїв у грунт вносять дедалі більше мінеральних та органічних добрив, а для боротьби зі шкідниками сільськогосподарських культур використовують різні отрутохімікати. Усе це крім позитивних наслідків має й негативні, поскільки хімічні сполуки значною мірою розчиняються у воді, потрапляючи у водойми.

Велику кількість води витрачає промисловість. Кожне виробництво має свої стічні води 3 певним вмістом шкідливих домішок. Раніше ці стоки розводили прісною водою, доводячи вміст шкідливих речовин до гранично допустимої концентрації, й лише після цього виливали у водойми. Однак із розвитком промисловості кількість стічних вод різко збільшилася, прісної води для розведення не вистачає, і при зливанні стічних вод концентрація шкідливих домішок перевищує гранично допустиму, що призводить до загибелі в водоймах живих організмів [6].

Найнебезпечнішими $€$ стічні води хімічної промисловості, що містять цинк, свинець, ртутні сполуки, хром, фтор, метанол, меланін [4].

Щоб запобігти забрудненню вод солями важких металів і звести до мінімуму надходження їх у стічні води та вжити відповідних природоохоронних заходів, Полтавський обласний державний проектно-технологічний центр охорони родючості грунтів і якості продукції проводить постійний моніторинг та оцінку якісного стану водних джерел області згідно 3 нормативним 


\section{СІЛЬСЬКЕ ГОСПОДАРСТВО. РОСЛИННИЦТВО}

документом: «Методические рекомендации по спектрофотометрическому определению тяжелых металлов в объектах окружающей среды, полимерах и биологическом материале» [5].

Аналіз основних досліджень і публікацій, у яких започатковано розв'язання проблеми. Проблема якісного водопостачання населення має планетарний характер. Боротьба за чисту питну воду є актуальною завжди, вона має багату історію й характеризується суто специфічними особливостями залежно від державного, регіонального та місцевого рівнів. Аналіз динаміки розвитку гігієнічного нормування якості питної води детально й професійно подано у роботі А. Гринзовського та М. Коршуна «сторичний нарис гігієнічного формування якості питної води» (2001) [3].

Безпечність питної води в європейському та українському водному законодавствах неодноразово розглядалися у працях М.В. Набока, С. А. Омельчука, Ю. А. Рахманіна, В. М. Шестопалова. Своєрідність підземних вод як екологічного об'єкта було виявлено багатьма науковцями. Зокрема, Г. С. Башмаков підкреслював, що для вирішення окремих проблем потрібне погодження водогосподарських та гірничих органів [1].

Серед найнебезпечніших забруднювачів води особливе місце належить важким металам. Вони відносяться до найбільш розповсюджених і небезпечних забруднюючих речовин, які широко використовуються у багатьох промислових виробництвах і зі стічними водами потрапляють до водойм та підземних водоносних горизонтів. Значна кількість цих сполук надходить також у воду через атмосферу й грунт. Екологічна небезпека важких металів полягає не тільки у безпосередньому їх впливі на організм, але й у тім, що вони активно поглинаються фітопланктоном і по харчовому ланцюгу можуть потрапити до організму людини.

Виділяють дві групи важких металів, різних за своєю екологічною значущістю.

До першої групи входять елементи, гранично допустимі концентрації (ГДК) яких близькі до їх фонових значень у природних водах (залізо, марганець, стронцій).

Друга група включає метали, ГДК яких значно перевищують реальні природні фонові значення. Це - мідь, свинець, цинк.

Токсичність водного середовища, забрудненого важкими металами, визначається не їх валовим вмістом, а передусім, їх фізико-хімічним складом. Найбільш токсичні вільні гідратовані іони металів, деякі неорганічні комплекси (в тому числі гідрокомплекси і металоорганічні спо- луки, так звані продукти метилування). У разі групування металів у комплекси 3 природними розчиненими органічними речовинами, як правило, відбувається детоксикація металів. Це, очевидно, добре еволюційно відпрацьований захисний механізм гідроекосистем, що дає їм змогу відновлюватися у випадку природних катаклізм, які супроводжуються викидом у гідросферу важких металів.

У Дніпровських водосховищах 60-70 \% свинцю перебуває у зваженому стані, що сприяє самоочищенню водоймища від цього металу; мідь, цинк і хром у водосховищах Дніпра переважно існують у розчиненому стані. Частка розчиненої форми становить 60-80 \% від їх загального вмісту. До особливо екологічно небезпечних зараховують також кадмій i алюміній, які за певних умов переважно зустрічаються у природній воді в іонній, найбільш токсичній формі. Ступінь переходу металів у комплекси дещо знижується наприкінці весни - початку літа. У цей час можливе підвищення токсичності води за рахунок збільшення концентрації вільних іонів металів [3].

Серед основних джерел забруднення гідросфери мінеральними речовинами і біогенними елементами є підприємства харчової промисловості та сільгосппідприємства. Зі зрошувальних земель щорічно вимивається близько 6 млн тонн солей, відходів, які містять ртуть, свинець, мідь [2]. Деяка частина їх виноситься далеко за межі територіальних вод. Забруднення ртуттю значно пригнічує розвиток фітопланктону. Відходи, що містять ртуть, зазвичай, концентруються у донних відкладеннях чи затоках рік. Подальша іï міграція супроводжується нагромадженням метилової ртуті та їі включенням у трофічні ланцюги водяних організмів, а далі й людини. Так, поширення набула хвороба Мінамата, що вперше була виявлена японськими вченими у людей, які вживали рибу, виловлену в затоці Мінамата, в яку безконтрольно скидали промислові стоки 3 техногенною ртуттю [2].

Загальновідомо, що ртуть і іï сполуки надзвичайно токсичні для людини: вони акумулюються в нирках, печінці, головному мозку. Основний орган-мішень для неорганічної ртуті - нирки. Ртуть вражає, передусім, центральну нервову систему. Летальна доза ртуті в разі споживання 3 питною водою становить 75-300 мг/добу. Симптоми ртутної інтоксикації - атаксія, пригнічення сприйняття та рефлексу кінцівок.

Кадмій має надзвичайно високу токсичність i кумулятивні властивості. Він знижує здатність організму людини протистояти хворобам, має мутагенні й канцерогенні властивості, впливає 


\section{СІЛЬСЬКЕ ГОСПОДАРСТВО. РОСЛИННИЦТВО}

на спадковість, а також руйнує еритроцити крові, сприяє захворюванню нирок і сім'яних залоз, викликає гастрит та анемію. Для людини допустима доза становить 70 мкг (для дорослих) і повністю виключає його наявність у питній воді та їі для дітей. Основним джерелом кадмію $є$ промислові викиди, значним носієм його є осади стічних вод. Із 100 т осаду в грунт вноситься 4-5 мг кадмію.

Істотним джерелом свинцю є осади комунальних і промислових стічних вод. У разі внесення у грунт близько 100 т/га стічних вод вміст свинцю в орному шарі підвищується на 4,5 мг/кг. Після перемішування з грунтом відходів, що містять свинець, він у значній мірі переходить у малорухомі сполуки; до того ж близько 20-30 \% його залишається в рухомому стані й засвоюється рослинами.

Мідь - один із незамінних елементів для організму людини. В деяких випадках дефіцит міді за симптомами подібний до хронічної інтоксикації нею. Надходження міді 3 їжею зазвичай становить 2-3 мг/добу, що підтримує необхідну рівновагу. Мідь малотоксична для людини, не має кумулятивних властивостей. Зазвичай, швидкість поглинання, утримання та виведення міді не призводять до підвищеного іiі вмісту в організмі.

Однак у випадку хвороб, що викликають порушення цього механізму, тривала абсорбція міді може викликати цироз печінки. Існують відомості про вплив міді на метаболізм штучно вигодуваних новонароджених. Зафіксовані гострі отруєння людей за вживання 3 питною водою міді в дозі 0,14 мг/кг і вище. Канцерогенні й мутагенні властивості міді не встановлені [4].

Мета досліджень. Основною метою дослідження є 3'ясування (на основі літературних даних) причин потрапляння солей важких металів у поверхневі та підземні води, а також постійний моніторинг якісного стану водних джерел Полтавської області.

Завдання дослідження - визначення вмісту солей важких металів у водах сільськогосподарського призначення у Полтавській області за 2008-2012 роки.

Методи дослідження. Дослідження виконувались у відповідності до існуючих нормативних актів та методичних вказівок. Визначення у джерелах вмісту свинцю, кадмію, цинку, міді та ртуті проводилися згідно 3 «Методическими рекомендациями по спектрофотометрическому определению тяжелых металлов в объектах окружающей среды, полимерах и биологических материалах» [5].
Результати дослідження. Проведення хімікоаналітичних досліджень здійснювалися в Полтавському обласному державному проектнотехнологічному центрі охорони родючості грунтів і якості продукції в атестованій випробувальній лабораторії, що має спеціалізовану аналітичну лабораторію, оснащену сучасними засобами вимірювальної техніки, випробувальним обладнанням.

Матеріалом для проведення досліджень були зразки води, що відбиралися в 2008-2012 роках.

Усього відібрано 61 пробу води, в тому числі: у водосховищах - 4, водоканалі - 1, ставках -6 , річках -17 , криницях - 16, водогонах -17 , а також 4 зразки 3 водосховищ - Кременчуцького (смт. Градизьк Глобинського району), Дніпродзержинського водосховища (с. Кишенька Кременчуцького району), с. Пулинці Лубенського району та с. Набережне Глобинського району. Один зразок із водоканалу Дніпро-Донбас (Новосанжарський район), шість зразків із ставків - с. Устивиця Великобагачанського району, м. Глобине, с. Кошманівка Машівського району, с. Трудолюб Миргородського району, с. Мале Ладижино Полтавського району, смт. Семенівка.

Сімнадцять зразків із річок - р. Псьол Великобагачанського та Кременчуцького районів, p. Середня Говтва Диканського району, p. Ворскла, що протікає територіями Кобеляцького, Котелевського та Полтавського районів, р. Оріль Новосанжарського району, р. Оржиця Оржицького району, р. Удай Пирятинського району, p. Коломак та р. Свинківка Полтавського району, p. Говтва Решетилівського району, р. Хорол Хорольського району, р. Многа Чорнухинського району.

Шістнадцять зразків із криниць - с. Поділ та с. Білоцерківка Великобагачанського району, м. Глобино, с. Вільхуватка Кобеляцького району, с. Любка Котелевського району, с. Кобелячок Кременчуцького району, с. Сенча Лохвицького району, с. Михнівці Лубенського району, с. Великі Сорочинці Миргородського району, с. Нехвороща Новосанжарського району, смт. Оржиця, с. Куликове та с. Степне Полтавського району, м. Хорол.

Сімнадцять зразків із водогонів - смт. В. Багачка, м. Глобино, смт. Диканька, смт. Котельва, м. Кременчук, м. Лохвиця, м. Лубни, смт. Машівка, м. Миргород, смт. Оржиця, м. Пирятин, м. Полтава, с. Куликове та с. Степне Полтавського району, смт. Семенівка, м. Хорол, смт. Чорнухи. Щорічно відбиралася в середньому 61 проба води. 
СІЛЬСЬКЕ ГОСПОДАРСТВО. РОСЛИННИЦТВО

Забруднення важкими металами вод сільськогосподарського призначення

\begin{tabular}{|c|c|c|c|}
\hline \multirow{2}{*}{ Хімічні елементи } & \multicolumn{3}{|c|}{ Вміст хімічних елементів, мг/л } \\
\hline & мінімальний & середній & максимальний \\
\hline \multicolumn{4}{|c|}{2008 рік } \\
\hline Цинк & 0,01 & 0,034 & 0,085 \\
\hline Мідь & 0,015 & 0,05 & 0,49 \\
\hline Кадмій & 0,00075 & 0,005 & 0,0097 \\
\hline Свинець & 0,005 & 0,03 & 0,097 \\
\hline Ртуть & 0,0005 & 0,001 & 0,0042 \\
\hline \multicolumn{4}{|c|}{2009 рік } \\
\hline Цинк & 0,02 & 0,08 & 0,46 \\
\hline Мідь & 0,01 & 0,03 & 0,06 \\
\hline Кадмій & 0,001 & 0,003 & 0,012 \\
\hline Свинець & 0,003 & 0,02 & 0,07 \\
\hline Ртуть & 0,0005 & 0,001 & 0,0042 \\
\hline \multicolumn{4}{|c|}{2010 рік } \\
\hline Цинк & 0,004 & 0,0043 & 0,4 \\
\hline Мідь & 0,005 & 0,037 & 0,115 \\
\hline Кадмій & 0,0008 & 0,0061 & 0,0075 \\
\hline Свинець & 0,0028 & 0,033 & 0,1 \\
\hline Ртуть & 0,0005 & 0,0011 & 0,0042 \\
\hline \multicolumn{4}{|c|}{2011 рік } \\
\hline Цинк & 0,023 & 0,46 & 0,267 \\
\hline Мідь & 0,02 & 0,026 & 0,05 \\
\hline Кадмій & 0,002 & 0,006 & 0,01 \\
\hline Свинець & 0,008 & 0,036 & 0,087 \\
\hline Ртуть & 0,0005 & 0,00084 & 0,0034 \\
\hline \multicolumn{4}{|c|}{2012 рік } \\
\hline Цинк & 0,019 & 0,042 & 0,156 \\
\hline Мідь & 0,022 & 0,088 & 0,269 \\
\hline Кадмій & 0,001 & 0,005 & 0,01 \\
\hline Свинець & 0,008 & 0,031 & 0,064 \\
\hline Ртуть & 0,0005 & 0,00084 & 0,0034 \\
\hline
\end{tabular}

Результати лабораторних досліджень подано в таблиці. Перевищення ГДК (гранично допустима концентрація ртуті становить 0,005 мг/л, кадмію - 0,01 мг/л, свинцю - 0,1 мг/л, цинку і міді 1,0 мг/л) не виявлено [7].

Аналіз вмісту важких металів у водних джерелах Полтавської області за 2008-2012 роки показує, що помітного перевищення забруднення води важкими металами не спостерігається.

Із даних таблиці видно, що забруднення у максимальному значенні у 2008 році по міді, свинцю та ртуті було дещо більшим, ніж у 2012 році, й складало, відповідно, 0,49, 0,097, 0,0042 мг/л. У той же час, у 2012 році дещо більший вміст спостерігався цинку і кадмію, ніж у 2008 році, й становив, відповідно, 0,156 та 0,01 мг/л.
Висновки: 1. Дослідження, що проводилися у 2008-2012 роках, показали, що води сільськогосподарського призначення Полтавської області не забруднені солями важких металів, тому $є$ перспектива ведення в даному регіоні екологічного землеробства. Однак необхідною передумовою цього залишається наявність об'єктивної інформації щодо агроекологічного стану грунтових і водних ресурсів, а також впровадження екологічно безпечних технологій вирощування сільськогосподарських культур.

2. Серед найнебезпечніших забруднювачів води особливе місце займають важкі метали, що відносяться до найбільш розповсюджених і небезпечних забруднюючих речовин. Вони широко використовуються у багатьох промислових ви- 


\section{СІЛЬСЬКЕ ГОСПОДАРСТВО. РОСЛИННИЦТВО}

робництвах і у складі промислових стічних вод потрапляють до водойм та підземних водоносних горизонтів. Значна кількість цих сполук надходить також у воду через атмосферу й грунт. Екологічна небезпека важких металів полягає не тільки у безпосередньому їх впливі на організм, але й у тім, що вони активно поглинаються фітопланктоном і далі по харчовому ланцюгу можуть потрапити до організму людини.

\section{БІБЛІОГРАФІЯ}

1. Бойко I. A. Адаптація українського законодавства до європейського в галузі управління якістю підземних вод. / I. А. Бойко // Вісник Полтавської державної аграрної академії. 2012. - №3. - С. 154.

2. Васюкова Г. Т. Екологія : підручник / Г. Т. Васюкова, О. І. Ярошева. - К. : Кондор, 2013. - 524 с.

3. Жуков В. Вода - життя, вода - здоров'я / В. Жуков, М. Щербань, Ю. Курськой // Стандартизація, сертифікація, якість. - 2003. - № 4. C. 5-11.

4. Коваль B. B. Динаміка забруднення вод сільськогосподарського призначеннясолями важких металів в умовах Полтавської області / В. В. Коваль, В. О. Наталочка, С. К. Ткаченко [та ін.] // Вісник Полтавської державної аграрної академії. - 2012. - №1. - С. 40-44.

5. Методические рекомендации по спектрофотометрическому определению тяжелых металлов
3. Для зменшення потрапляння в організм людини токсичних речовин і їх негативної дії необхідно постійно проводити моніторинг вод сільськогосподарського призначення на вміст солей важких металів, вживаючи заходів щодо зменшення їх потрапляння у природні водойми, а також систематично інформувати населення через засоби масової інформації про стан водних ресурсів у даному регіоні.

в объектах окружающей среды, полимерах и биологическом материале. - Одесса : Одесский филиал НИИ гигиены водного транспорта. 1986. -28 c.

6. Наукові звіти Полтавськогорегіонального управління водних ресурсів за 2008-2012 роки.

7. Наукові звіти Полтавського центру «Облдержродючість» про проведення проектнотехнологічних робіт за 2008-2012 роки.

8. Синяк B. B. Шляхи забезпечення якісною водою населення України / Доповідь на Міжнародній науково-практичній конференції «Ресурси природних вод Карпатського регіону». Львів, 4-5 квітня 2002 р. - 5 с.

9. Школьник Л. Питна вода - номер перший у порядку денному / Л. Школьник // Стандартизація, сертифікація, якість. - 2003. - №4. - С. 3. 